\title{
Nature or Nurture - Will Epigenomics Solve the Dilemma?
}

\section{Beata Płonka}

Department of Biophysics

Faculty of Biochemistry, Biophysics and Biotechnology

Jagiellonian University, Kraków,

Poland

e-mail: beata.plonka@uj.edu.pl

\begin{abstract}
:
The concept of "nature and nurture" is used to distinguish between genetic and environmental influences on the formation of individual, mainly behavioral, traits. Different approaches that interpret nature and nurture as completely opposite or complementary aspects of human development have been discussed for decades. The paper addresses the most important points of nature vs nurture debate from the perspective of biological research, especially in the light of the recent findings in the field of epigenetics. The most important biological concepts, such as the trait, phenotype and genotype, as well as the evolution of other crucial notions are presented. Various attempts to find the main source of human variation are discussed - mainly the search for structural variants and the genome-wide association studies (GWAS). A new approach resulting from the discovery of "missing heritability", as well as the current knowledge about the possible influence of epigenetic mechanisms on human traits are analyzed. Finally, the impact of epigenetic revolution on the society (public attitude, health policy, human rights etc.) is discussed.

Keywords: nature, nurture, behavioral traits, behavioral genetics, missing heritability, epigenetics.
\end{abstract}

\section{Introduction}

The phrase "nature and nurture" is applied in discussion of the influence of innate, hereditary factors ("nature") in comparison to environmental influences ("nurture"), on the formation of individual traits (most frequently used in relation to human behavioral traits). The modern version of the "nature vs nurture" concept was introduced in the late nineteenth century by Francis Galton, who was also the founder of eugenics (meaning "being of good birth" or "noble in heredity"). Galton, who was influenced by the work of Charles Darwin (especially On the Origin of Species) believed in the dominance of heredity in the formation of human traits. His eugenics program incorporated some rules derived from plant and animal breeding used in husbandry and transferred 
them on human race improvement and social advancement in the form of the so-called negative and positive eugenics. " The concepts of "nature" and "nurture" had been used before ${ }^{2}$, but Galton treated them as opposites, thus creating "nature vs nurture" dichotomy (alternative). This fact was pointed out by E. Fox-Keller:

Galton was hardly the first to write about nature and nurture as distinguishable concepts, but he may have been the first to treat them as disjoint. As far as I can tell, such an assumption of mutual exclusivity was not made by earlier writers. For those who used the terms, nurture was rarely, if ever, seen as separable from nature; instead, it was referred to as helping and assisting, or as responding to, nature; nurture was more of a verb than a noun. But those writing after Galton did tend to disjoin the two, increasingly so over time. What is especially noteworthy to me is that the shift in formulation followed directly on the heels of the introduction of a particulate theory of inheritance in the last third of the nineteenth century. Indeed, I argue that this shift was greatly assisted by the arrival of a new way of conceptualizing heredity, and perhaps even dependent upon it $\left[59\right.$, p. 11]..$^{3}$

It must be stressed however that the "nature and nurture" concept highlights a crucial biological phenomenon of mutual influences of both hereditary and environmental factors in the trait formation. Nature and nurture can be viewed as complementary or opposite to one another, but the main dilemma concerns the relative importance of both sorts of factors. There are many different interpretations of the dilemma, from the extreme genetic determinism to the "blank slate" (tabula rasa) view. The "blank slate" concept, linking development of human behavioral traits solely with environmental influences is usually attributed to John Locke. Such a notion, however, is clearly an oversimplification, as "innate ideas are not the same as innate dispositions" [59, p. 18]. Moreover, Locke clearly suggested to take these innate dispositions into consideration during the education process:

we shall see whether what is required of him be adapted to his capacity, and any way suited to the child's natural genius and constitution; for that too much be considered in a right education. We must not hope wholly to change their original tempers, nor make the gay pensive and grave, nor the melancholy sportive, without spoiling them. God has stamped certain characters upon men's minds, which like their shapes, may perhaps be a little mended, but can hardly be totally altered and transformed into the contrary. He therefore that is about children should well study their natures and aptitudes, and see by often trials what turn they easily take, and what becomes them; observe what their native stock is, how it may be improved, and what it is fit for: he should consider what they want, whether they be capable of having it wrought into them by industry, and incorporated there by practice; and whether it be worthwhile to endeavor it $[117, \S 66$, loc. 831-839].

Extreme genetic determinism and "blank slate" view are two opposite approaches to the development of human behavioral traits that has been in conflict for decades, supporting various educational agendas and ideologies. It is now widely accepted by biologists that both hereditary and environmental factors have substantial influence on the formation of human traits, so the most extreme views are clearly outdated. We will try to present and discuss the evolution of naturenurture approaches from the perspective of biological research. 


\section{Genes, Phenotypic Traits, and Missing Heritability}

We have already described the concept of "nature and nurture" in terms of the relative influence of hereditary and environmental factors on the individual traits. We will try to analyze this problem from the perspective of particular traits so we must define the meaning of a "trait" first. The term is used in biological sciences as an attribute (feature, characteristic) of an organism, as accurately described by M.J. West-Eberhard:

A 'trait' is simply a somewhat discrete characteristic of an organism. It could be an aspect of morphology, a physiological state, a behavior, a molecule, or a disease, but the implication is that it is a product of development that is qualitatively distinct relative to other aspects of the organism [...] In addition to the discrete on-off qualitative traits of organisms, there are other traits, such as body size or longevity, that are "quantitative traits" - features that are described in terms of their numerically measurable (quantifiable) values (e.g., weight, mass, or life span). Discrete, qualitative traits have dimensions (for example, the length of a bone, the duration of a behavior) that can be measured as quantitatively variable traits ${ }^{4}$.

There is also another important biological term - "phenotype" applied to the observable characteristics (biochemical or physical) of an organism. The term may be used in a broader (general) meaning to address all observable traits of an individual, but it can also refer to particular traits, such as blood type or eye color. In general, the term "phenotypic trait", if applied to humans, describes any aspect of anatomy, morphology or physiology ("biological traits"), but also our cognitive abilities, emotions or personality (behavioral traits). Typically, the term "trait" is used in a sense of a "phenotypic trait", as opposed to the genotype. The term "genotype" can also have a broad meaning and describe the entire set of genes (genetic constitution of an organism), or just refer to the variants of a particular gene (alleles). Humans, as diploid organisms, have two alleles of any gene - at a specific genetic locus (position). The genotype of an individual is described as homozygous if it has two identical alleles in a specific locus, and with two different alleles - as heterozygous. Phenotypic traits result from complex interactions between genes and environment, with a large number of genes involved in the formation of the so-called polygenic traits. There is a substantial variance among traits in the level of environmental influence, from the traits determined almost exclusively by the genes, to the traits that are formed to a large extent by environmental factors. Genetically identical twins that are not, in fact, phenotypically identical, are a great example of the trait-environment relations. Environmental factors influence every individual in a unique way and order, changing its internal environment and affecting subsequent processes of gene expression [124].

The mechanisms of the genome-environment interactions in the trait formation are the main focus of biologists, and the relative impact of both hereditary and external factors is the key aspect of the "nature and nurture" problem. The main question about the basis of phenotypic differences in human populations has been often answered according to the genetic determinism view. This solution led to the belief that human traits are determined by genes and other influences are of minor importance (if any at all). We are well aware of the genetic diversity among individuals in a human population, but the extent of this variation is not fully understood yet. ${ }^{5}$ The general trend of searching for genetic variants that can be associated with particular human phenotypic traits is especially apparent in the so-called genome-wide association study (GWAS). The GWAS analyses, however, has been primarily focused on the genetic diversity at a single position in the genome (single nucleotide polymorphism - SNP) [85]. ${ }^{6}$ There is a growing body of evidence, however, that structural variations (genomic alterations involving DNA fragments $>1 \mathrm{~kb}$ ) play much more prominent role in the genetic variation than previously assumed, with up to $13 \%$ of the human 
genome being subject to structural variations [27, 48, 53, 95, 196]. Feuk L., Carson A.R. and Scherer W. describe this change in their crucial paper:

The first wave of information from the analysis of the human genome revealed SNPs to be the main source of genetic and phenotypic human variation. However, the advent of genome-scanning technologies has now uncovered an unexpectedly large extent of what we term 'structural variation' in the human genome [...] Rapidly accumulating evidence indicates that structural variants can comprise millions of nucleotides of heterogeneity within every genome, and are likely to make an important contribution to human diversity and disease susceptibility [53].

One kind of structural variations (the so-called copy number variants $-\mathrm{CNVs}^{7}$ seem to have a particularly strong impact on phenotypic diversity, especially complex traits [27, 65, 79, 196]. The number of copies of salivary amylase gene varies among humans (up to 10 copies), with multiple copies leading to higher amylase levels and the ability to digest the starch in food. It is an interesting example of the influence of diet on the genetic variation in human populations [100, 148]. Lactase persistence, a uniquely human trait, is yet another example of the diet-driven changes in human diversity, but it is also interpreted as a case of the influence of culture on human evolution. ${ }^{8}$ The ability to digest lactase after childhood is prevalent in populations with diet strongly dependent on milk and a long tradition of dairy herding. Moreover, this ability may have various genetic backgrounds and has appeared several times independently in human populations in Europe, Africa and the Middle East in the past 10,000 years [100]. ${ }^{9}$ This is, as pointed out by Kingsley D.M. "a striking example of the repeated evolution of a similar trait by independent changes affecting one gene [...] Its retention in milk-dependent societies also illustrates how culture can reinforce the forces of evolution." [100, p. 58-59].

Many years of genomic research has revealed the basic fact - the links between genes and appropriate phenotypic traits are complex, non-linear and often unpredictable. The diversity of DNA sequence in the human population (DNA sequence variants) has been the focus of genetic studies of complex traits. There can be a wide spectrum of possible effects an allele can have on the phenotype - from a huge impact (e.g. in single gene disorders), moderate size effects of several alleles and small effects of many alleles, to the cumulative impact of a very big number of variants [124]. All these facts have diminished expectations of finding simple answers to the question about the impact of heredity on human features and abilities. It has not deterred researchers from pursuing correlations between genes and particular human traits, but subsequent discoveries have again challenged some of our notions.

An ambitious goal of sequencing human genome and locating all genes has been established for the Human Genome Project. The discovery of approximately 23,500 genes in the human genome had come as a great surprise, which has been further increased by finding direct links between traits and only $1.5 \%$ of the genome. It means we know very little about the function of about $98.5 \%$ of our genome, and this "chunk" is often described as "the dark matter of the genome" $[12,107,108,197]^{10}$

Therefore, it has even become necessary to find a new definition of the "gene", as the old ones have become outdated. ${ }^{11}$ The first concept of the gene comes from the work of Gregor Mendel (1866) and means an abstract element of heredity, acting as a distinct, discrete unit. There have been other definitions, such as gene as a distinct locus (Thomas Morgan 1915), "gene as transcribed code" (1960s), "gene as an open reading frame (ORF) sequence pattern" or "annotated genomic entity enumerated in the databanks" (1990s-2000s) [68, p. 670]. The topic was so important and controversial that 25 experts involved in the Sequence Ontology Consortium spent nearly two days in heated discussion to reach the consensus. Finally, a tentative definition was created of a gene as "a locatable region of genomic sequence, corresponding to a unit of inheritance, which is associated 
with regulatory regions, transcribed regions and/or other functional sequence regions" [143, p. 401]. ${ }^{12}$

The search of genetic basis of human complex traits during the genome-wide association studies (GWAS) has revealed that the major portion of heritability estimated in previous studies cannot be explained $[117,120,121,191]$. This discovery has led to questions concerning the factual extent of genetic factors in the trait formation and the term "missing heritability" has been applied to it. ${ }^{13}$ Some researchers focus mainly on improving resolution of GWAS techniques (ability to detect small-effect variants) as well as statistical methods of data analysis to prove the dominance of genetic factors [10,34, 120, 210]. There is also another trend, however, as scientists start to acknowledge the crucial role of environmental factors for phenotypic traits. This change of view has been strongly influenced by the evidence of the importance of epigenetic effects, which will be discussed later. Clarke A.J. \&, Cooper D.N. summarize the dilemma:

So, where is this 'missing heritability'? We respond to this question in two different ways. First, we believe that complex disorders are indeed complex and that genetic studies of complex disorders in humans face a number of challenges including genegene and gene-environment interactions and epigenetic modification of the genome. Second, we shall argue that high estimates of heritability have been misinterpreted as showing that a predisposition to such a condition (one with high heritability) must have been transmitted through the family from parent to child. The complexity of these common conditions is apparent from the range of factors that need to be considered as potentially contributing to the 'missing heritability [26].

\section{Genes and Behavioral Traits}

The most controversial aspect of the "nature and nurture" problem concerns human behavioral traits that are studied by behavioral genetics. Decades of research has found numerous genes associated with such traits as cognitive or language abilities, but there is also a lot of misunderstanding concerning these discoveries. There is a marked tendency to focus solely on the genetic background of traits in a clearly deterministic way, coupled with the neglect of other factors. Despite the fact that relations of traits to both heredity and environment have been proven to be extremely complex, they are seldom perceived in that way, especially by the general public. This way of thinking, which can be observed even among scientists, is criticized by Y. Levy and R.P. Ebstein. They point out that

there have been quite a few articles in which a plea has been made to behavioral scientists to revise their misconceptions about gene-behavior correlates if they hope to 'untangle the webs that link genes to cognition' (Fisher, 2006, p. 270). A frequent misunderstanding concerns talk about 'smart genes', 'language genes' or 'aggressive genes'. Such talk implies direct pathways from genes to complex behaviors, whereas biology tells us that those routes are multifaceted and nonlinear (Marcus \& Fisher, 2003). Furthermore, such discourse neglects the role played by the intricate sets of ontogenetic factors, environments, developmental timing and stochastic events on the behavioral outcome (Rutter, Moffitt, \& Caspi, 2006)" [111, p. 657].

One of the most famous examples of such an attitude was the FOXP2 gene, generally described as a "language gene". The product of the gene (transcription factor (forkhead box P2) Foxp2) indeed plays an important role in speech and language development. Some mutations of FOXP2 are associated with severe speech and language disorders - mainly verbal dyspraxia (SPCH1; speechlanguage disorder 1) and specific language impairment (SLI) $[56,57,113,123] .{ }^{14}$ It is a great 
oversimplification, however, to call FOXP2 a "language gene", as human language abilities are linked with many other genes. ${ }^{15}$ Moreover, many of these genes that had been associated with certain abilities (like speech and language) may have pleiotropic effect and influence other behavioral traits. It has been proven, apart from already mentioned FOXP2 gene, also for KIAA0319, ROBO1, DYX1C1 and DCDC2 genes that affect mathematics abilities [125, 126].

In general, genetic overlap between traits (pleiotropy) is evident for various aspects of human cognitive abilities, such as general cognitive ability (verbal and non-verbal intelligence) as well as learning abilities (mathematics, reading and language skills). The influence of particular genes on diverse aspects of cognitive abilities revealed in twin studies has been accounted for in the Generalist Genes Hypothesis, but has also been confirmed by the Genome-wide Complex Trait Analysis, correlating genomic and phenotypic similarities across large populations [152, 193]. ${ }^{16}$ Discrepancies between heritability estimates from twin studies and data obtained from genomewide complex trait analyses (GCTA) have been especially huge for behavioral traits. The most striking example concerns behavior problems in childhood, as no significant genetic influence has been detected by GCTA, whereas twin studies estimates are about $40 \%$ for anxiety or depression and approximately $60 \%$ for hyperactivity and autistic symptoms. In general, the average twin heritability for both cognitive abilities and behavior problems are estimated for $50 \%$, but GCTA heritability is about $25 \%$ and $12 \%$, respectively [192]. It is interesting, however, that authors interpret these data in a strictly "genetic" way, focusing on difficulty with identifying appropriate genes due to the dominance of nonadditive genetic influence in behavior problems. The assumptions have remained, although the techniques have changed - the search for candidate genes has been replaced by looking for polygenic scores in genome-wide analyses of extremely large samples.

The gene-environment interaction has become a focus of many researchers in recent years, providing some valuable data $[18,22,80,84,140,181]$. However, small samples, various model tests and high flexibility in data acquisition and analysis result in the high false positive rates and low replicability of the research estimating gene-environment interactions, a problem frequent in psychological studies $[23,39,40,43,175]$.

An interesting view on main trends in behavioral genetics is presented by E. Turkheimer, a behavioral geneticist himself. He points out that due to the genetic and environmental influences on traits, the main question in the nature/nurture debate concerns the importance of knowledge gained from genetic analyses:

What should we expect from the modern genomic era's signature enterprise - the search for co-variation between measured DNA and behavior? [...] If genes influence behavior and sample sizes are large enough, significant associations between DNA and behavioral differences will be found. The important question is whether the associations will mean anything [195, p. 26].

The problems with replication of data stem from the complexity of human development and behavior that are extremely sensitive to the genetic and environmental context, so it is impossible to maintain experimental control over most of the conditions [195]. Turkheimer also criticizes the abuse of significance testing of experimental data, which has just become the so-called " $p$-fishing" (or " $p$-hacking"). He states:

In genomewide-association studies, data on hundreds of thousands of individual bits of DNA are collected in large samples and then searched for significant results at highly stringent $\mathrm{p}$ levels. If (as usually happens) no significant results are discovered the first time around, the process is repeated with even larger samples, continuing until 
something significant finally emerges [...] Genome-wide association is unapologetic, high-tech p-hacking [195, p. 27]. ${ }^{18}$

If behavioral genetics continues to fall into these traps in blind search for scientific significance its results will be in danger of losing genuine psychological meaning. The tendency is still strong, although ground-breaking discoveries of the epigenetic mechanisms have shifted attention to environmental influence on trait formation.

\section{Epigenetic Revolution}

The theory of Jean-Baptist Lamarck formulated early in the nineteenth century postulated that acquired characteristics of an individual are hereditary. The theory was abandoned a long time ago, but it has been revived recently and even the term "neo-lamarckism" is now occasionally used [9, 16, 178]. This possibility was once again taken into consideration after the surprising discovery of epigenetic mechanisms in trait formation. Epigenetic modifications can alter gene expression without changing the sequence of the genome and may be triggered by environmental factors such as diet and nutrition status, stress, exposure to toxic compounds or pharmacological treatment. The epigenetic changes accumulate during lifetime, increasing variation in the human population that can be observed even for monozygotic twins [17, 60, 191]. Epigenetic mechanisms have been implicated in certain diseases, such as syndromes involving mental retardation [44], cancer [31], diabetes and obesity [42].

The epigenetic changes result mainly from DNA methylation (by DNA methyltransferases) and post-translational histone modifications. The mechanisms of DNA methylation and demethylation are of particular importance as the balance between these processes strongly affects the gene expression dynamics [45, 162]. Another mechanisms of epigenetic regulation are connected with histone methylation and acetylation, changes in chromatin organization (e.g. activity of chaperones) as well as involvement of various types of RNA (such as specific mRNAs and siRNAs/miRNAs or ncRNAs) [112, 115, 162, 166, 213].

There is a growing body of evidence of the importance of epigenetic regulation in behavioral and cognitive processes [71]. Epigenetic influence has been observed in brain development and neuroplasticity [2, 49, 50, 154, 163, 173], neuron differentiation [86], also learning and memory formation [24, 28, 37, 51, 54, 90, 144], including fear memory formation [77, 89, 131]. Epigenetic mechanisms are also involved in aging, neurological diseases, mood and psychotic disorders, cognitive impairments or response to trauma [19, 50, 83, 144, 163, 169, 173]. There are also data concerning epigenetic changes in the brain that may lead to certain behavior, like suicide [1] or increased susceptibility to schizophrenia [63].

Epigenetic mechanisms mediate the impact of early-life experiences, such as malnutrition and exposure to toxicants (especially in prenatal stage), but also social environment, stress, adversity, abuse or trauma [74, 97, 106, 118, 146, 156, 167, 183, 184, 186, 187], and prenatal maternal stress affects the offspring [20]. On the other hand, such factors as physical activity, social interactions or enriched living conditions can lead to positive epigenetic changes [122].

There are also data suggesting the involvement of epigenetic mechanisms in changes caused by parenting. The fact that maternal care in mice and rats changes epigenetic programming has been proven by many authors $[30,169,186,198]$ and has also been observed for humans $[126,135]$.

Epigenetic mechanisms are also suggested to be the basis of the Flynn effect [73]. The Flynn effect refers to the generational increase in measured intelligence scores (IQ) observed in the general population, and was popularized by James Flynn [58]. This phenomenon, estimated for about three points of IQ score per decade, has been observed at least since the 1930s, but there is some evidence the rise started even in 1917 (Tuddenham, 1948). The Flynn effect was confirmed across different age groups, tests and populations $[149,190]$. 
There are a lot of data confirming the importance of epigenetic effect on individuals during their lifetime. The real transgenerational inheritance, however, is still under debate, especially for humans [32, 33, 52, 75, 81, 87, 88, 114]. There is some evidence of transmission of epigenetic changes through the germ line $[5,13,25,130,203]$, as the erasure of methylation marks seems to be incomplete in mammalian cells $[114,158]$. Moreover, various kinds of RNA has been detected in gametes, that can influence chromatin remodeling and gene expression [78, 93, 99, 101, 102, $112,132,165,209]$. Epigenetic changes have been observed in paternal germ cell programming due to severe social defeat, chronic stress, traumatic experience, conditioned fear, cocaine exposure or dietary change in mice $[7,164]$.

Several studies revealed the link between environmental stress or prenatal malnutrition and chronic diseases up to the second generation [82, 141, 179], while early life circumstances influence longevity [94]. Exposure to various xenobiotics and chemicals (e.g. in environment) may lead to many diseases and abnormalities, including behavioral changes, even down to the fourth generation $[5,15,29,92,103,139,177,180,207]$. There are also data suggesting that prenatal immune activation can affect brain development and behavioral traits down to three generations [201].

The most important and interesting question concerns the epigenetic transgenerational inheritance of individual experience. It has been proven that parental odor experience (including olfactory fear conditioning) is transferred to subsequent generations in mice [37, 38,185]. Several observations suggest the beneficial effect of enriched environment early in life that is transferred to the next generations in animals [6, 176]. Early life stress due to maternal separation induces alteration of some behavior (risk assessment, novelty response, social behavior) across three generations in mice [61, 204], but the effect can be diminished by environmental enrichment [67]. Severe social stress in adult mice may lead to anxiety and depressive-like behavior in the progeny [41]. Recent data suggest that anxiety and stress-reactive traits can be transmitted across multiple generations [130] and point to the link between parental stress, violence exposure and PTSD in humans and epigenetic changes in the offspring [14, 96, 109, 147, 155, 208, 211].

The examples of empirical evidence presented here suggest strong connections between environment and trait formation via epigenetic mechanisms. The epigenetic effects are particularly well documented in animals, even in the case of transgenerational transfer. The evidence of these effects in humans is still relatively scarce, so their significance and magnitude remain to be ascertained. The controversy also stems from the lack of clear definitions of various "modes" of inheritance (e.g. epigenetic) and the complexity of human development so broader definition of non-genetic inheritance is required $[135,137,189]$. The strongest evidence of transgenerational inheritance of traits acquired through experience concerns the influence of parental PTSD and exposure to severe trauma on the risk for psychopathology in the offspring. It is extremely difficult (or even impossible) to differentiate between genetic, behavioral and epigenetic (non-genetic, nonbehavioral) ways of transmission of behavioral traits, so the data must be treated with caution.

\section{Epigenetics and Society}

Epigenetics explain how environmental factors promote changes in living organisms, contributing to the nature/nurture discussion and challenging the previously established opposition. Despite the fact that many issues are still unresolved, current findings suggest a strong impact of "nurture" on individuals, sometimes even stronger than "nature". It cannot also be denied that the discovery of epigenetic mechanisms has created new perspectives in biology. Epigenetic effects allow for better understanding of complex interactions between living organisms and environment that modify traits in individuals. The ground-breaking work on the influence of the early life experiences on the health and behavior later in life $[170,188,200]$ has led to "an explosion of interest in so-called epigenetic mechanisms of gene regulation in the brain" [129, p. 24]. These discoveries added new meaning to the nature/nurture discussion, but also created a danger of focusing solely on molecular 
mechanisms with exclusion of more complex (social, economic or political) aspects of analyzed situations. Margaret Lock points out that it

raises concerns that we may well be entering an era that is embracing a new form of somatic determinism. Although the contribution of environments, social and physical, to human development, health, and illness, are now well recognized, there is a distinct danger that the molecular endpoints that these variables bring about, and very little else, will receive due attention [...] Over the course of the twentieth century, molecular reductionists have time and again made headway by black-boxing the social. Epigenetics, it seems, has the potential to bring about an end to this situation, but it remains to be seen whether it will transcend the hegemony of molecularized biological determinism [116, pp. 292, 304].

The problem of epigenetic determinism was also discussed by other authors [199].

On the other hand, this "epigenetic revolution" may be used to make unsubstantiated claims by media commentators or politicians and create huge expectations in society. Maurizio Meloni and Giuseppe Testa present a thorough discussion of scientific controversies surrounding epigenetics and their potential impact on social theories \& policies. They point out the rift between scientific debate and public opinion:

It is in this mismatch between what is established and what is at present a source of heated scientific dispute that speculative assumptions, inflated discourses and enthusiastic media promotion, in a word all that create hypes around the epigenetic imaginary, are likely to find fertile ground [128, p. 439].

These unrealistic expectations stem partly from both the success and shortcomings of genomics that failed to deliver the complete understanding of human diversity and health risks. The post-genomic era brings new promises that we are eager to embrace.

Rapidly increasing popularity of a new research field known as Developmental Origin of Health and Disease (DOHaD) is a particularly striking example of this trend. In the light of evidence concerning the importance of prenatal growth it seems reasonable that we should "support mothers to secure future public health" as David Barker states in his commentary [8]. Proper policy and public awareness (especially among pregnant women) could have beneficial effects, but we definitely shouldn't "jump in without checking the water level". Sarah S. Richardson warns against the irresponsible discussion as " $\mathrm{DOHaD}$ would ideally guide policies that support parents and children, but exaggerations and over-simplifications are making scapegoats of mothers, and could even increase surveillance and regulation of pregnant women" [160, p. 131]. ${ }^{19}$ This tendency that can justify constraining women's freedom and lead to their objectification is now evident in some publications and discussions. Richardson summarizes it perfectly:

As an epigenetic vector, the maternal body is at once a background element, a medium for the fetus. Yet it is also a "critical" developmental context in which environmental exposures are amplified, cues are transmitted, and genes are programmed. In epigenetic explanations, elements of agency, control, and intervention mix ambiguously with models of nondirective, inertial developmental systems $\left[159\right.$, p. 225]. ${ }^{20}$

The knowledge about epigenetic effects can be used properly for example to promote better health outcome or counteract social and racial discrimination [72,105], especially if transgenerational transmission of personal experience would be finally proven. The possibility of such a transfer shouldn't be ignored, even if it places more responsibility on us for the society we create. This 
responsibility, however, should be treated with special consideration in order to avoid bad social and health policies based on inflated expectations, exaggerations and over-simplifications. Such an outcome is particularly probable as we often succumb to the overwhelming desire of finding simple answers to complex questions. It can be extremely difficult to find a balance between the responsibility for future generations and human rights of actually living individuals. We must also remember that the knowledge gained in the post-genomic era can become a powerful tool of abuse in the hands of well-meaning, scientifically-enlightened tyrants.

\section{Acknowledgement}

This article was written with the support of the Polish National Science Centre Fund (2012/07/D/HS1/01099).

\section{References}

1. Akbarian, S., Halene, T. The neuroepigenetics of suicide. The American Journal of Psychiatry 170(5), 2013, pp. 462-465.

2. Aksoy-Aksel, A., Zampa, F., Schratt, G. MicroRNAs and synaptic plasticity--a mutual relationship. Philosophical Transactions of the Royal Society of London. Series B, Biological Sciences 369(1652), 2014.

3. Alexander, R. P., Fang, G., Rozowsky, J., Snyder, M., Gerstein, M. B. Annotating non-coding regions of the genome. Nature Reviews. Genetics 11(8), 2010, pp. 559-571.

4. Anthoni, H., Zucchelli, M., Matsson, H., Müller-Myhsok, B., Fransson, I., Schumacher, J., Massinen, S., Onkamo, P., Warnke, A., Griesemann, H., Hoffmann, P., Nopola-Hemmi, J., Lyytinen, H., Schulte-Körne, G., Kere, J., Nöthen, M. M., Peyrard-Janvid, M. A locus on 2p12 containing the co-regulated MRPL19 and C2ORF3 genes is associated to dyslexia. Human Molecular Genetics 16(6), 2007, pp. 667-677.

5. Anway, M. D., Cupp, A. S., Uzumcu, M., Skinner, M. K. Epigenetic trans-generational actions of endocrine disruptors and male fertility. Science 308, 2005, pp. 1466-1469.

6. Arai, J. A., Li, S., Hartley, D. M., Feig, L. A. Transgenerational rescue of a genetic defect in long-term potentiation and memory formation by juvenile enrichment. Journal of Neuroscience 29, 2009, pp. 1496-1502.

7. Bale, T. L. Lifetime stress experience: transgenerational epigenetics and germ cell programming. Dialogues in Clinical Neuroscience 16(3), 2014, pp. 297-305.

8. Barker, D., Barker, M., Fleming, T., Lampl, M. Developmental biology: Support mothers to secure future public health. Nature 504(7479), 2013, pp. 209-211.

9. Barry, G. Lamarckian evolution explains human brain evolution and psychiatric disorders. Frontiers in Neuroscience 7, 2013, pp. 224.

10. Berger, S., Pérez-Rodríguez, P., Veturi, Y., Simianer, H., de los Campos, G.. Effectiveness of shrinkage and variable selection methods for the prediction of complex human traits using data from distantly related individuals. Annals of Human Genetics 79(2), 2015, pp. 122-135.

11. Bersaglieri, T., Sabeti, P. C., Patterson, N., Vanderploeg, T., Schaffner, S. F., Drake, J. A., Rhodes, M., Reich, D. E., Hirschhorn, J. N. Genetic signatures of strong recent positive selection at the lactase gene. American Journal of Human Genetics 74(6), 2004, pp. 1111-1120.

12. Blaxter, M. Genetics. Revealing the dark matter of the genome. Science 330(6012), 2010, pp. 1758-1759.

13. Bohacek, J., Gapp, K., Saab, B. J., Mansuy, I. M. Transgenerational epigenetic effects on brain functions. Biological Psychiatry 73(4), 2013, pp. 313-320.

14. Bowers, M. E., Yehuda, R. Intergenerational transmission of stress in humans. Neuropsychopharmacology 41(1), 2016, pp. 232-244. 
15. Bromer, J. G., Wu, J., Zhou, Y., Taylor, H. S. Hypermethylation of Homeobox A10 by in utero diethylstilbestrol exposure: An epigenetic mechanism for altered developmental programming. Endocrinology 150, 2009, pp. 3376-3382.

16. Burggren, W. W. Epigenetics as a source of variation in comparative animal physiology - or Lamarck is lookin' pretty good these days. The Journal of Experimental Biology 217(Pt 5), 2014, pp. 682-689.

17. Burggren, W. W., Crews, D. Epigenetics in comparative biology: why we should pay attention. Integrative and Comparative Biology 54(1), 2014, pp. 7-20.

18. Button, T. M., Lau, J. Y., Maughan, B., Eley, T. C. Parental punitive discipline, negative life events and gene-environment interplay in the development of externalizing behavior. Psychological Medicine 38(1), 2008, pp. 29-39.

19. Cacabelos, R., Torrellas C. Epigenetics of aging and Alzheimer's disease: Implications for pharmacogenomics and drug response. International Journal of Molecular Sciences 16(12), 2015, pp. 30483-30543.

20. Cao-Lei, L., Elgbeili, G., Massart, R., Laplante, D. P., Szyf, M., King, S. Pregnant women's cognitive appraisal of a natural disaster affects DNA methylation in their children 13 years later: Project Ice Storm. Translational Psychiatry 5, 2015, p. e515.

21. Cargill, M., Altshuler, D., Ireland, J., Sklar, P., Ardlie, K., Patil, N., Shaw, N., Lane, C. R., Lim, E. P., Kalyanaraman, N., Nemesh, J., Ziaugra, L., Friedland, L., Rolfe, A., Warrington, J., Lipshutz, R., Daley, G. Q., Lander, E. S. Characterization of single-nucleotide polymorphisms in coding regions of human genes. Nature Genetics 22(3), 1999, pp. 231-238. Erratum in: Nature Genetics 23(3), 1999, p. 373.

22. Caspi, A., Sugden, K., Moffitt, T. E., Taylor, A., Craig, I. W., Harrington, H., Poulton, R. Influence of life stress on depression: moderation by a polymorphism in the 5-HTT gene. Science 301, 2003, pp. 386-389.

23. Chabris, C. F., Hebert, B. M., Benjamin, D. J., Beauchamp, J., Cesarini, D., van der Loos, M., Johannesson, M., Magnusson, P. K., Lichtenstein, P., Atwood, C. S., Freese, J., Hauser, T. S., Hauser, R. M., Christakis, N., Laibson, D. Most reported genetic associations with general intelligence are probably false positives. Psychological Science 23(11), 2012, pp. 1314-23.

24. Chen, C., Meng, S. Q., Xue, Y. X., Han, Y., Sun, C. Y., Deng, J. H., Chen, N., Bao, Y. P., Zhang, F. L., Cao, L. L., Zhu, W. G., Shi, J., Song, W. H., Lu, L. Epigenetic modification of PKM $\zeta$ rescues aging-related cognitive impairment. Scientific Reports 6, 2016, p. 22096.

25. Chong, S., Whitelaw, E. Epigenetic germline inheritance. Current Opinion in Genetics \& Development 14, 2004, pp. 692-696.

26. Clarke, A.J., Cooper, D.N., GWAS: heritability missing in action? European Journal of Human Genetics 18, 2010, pp. 859-861.

27. Conrad, D. F., Pinto, D., Redon, R., Feuk, L., Gokcumen, O., Zhang, Y., Aerts, J., Andrews, T. D., Barnes, C., Campbell, P., Fitzgerald, T., Hu, M., Ihm, C. H., Kristiansson, K., Macarthur, D. G., Macdonald, J. R., Onyiah, I., Pang, A. W., Robson, S., Stirrups, K., Valsesia, A., Walter, K., Wei, J., Wellcome Trust Case Control Consortium, Tyler-Smith, C., Carter, N. P., Lee, C., Scherer, S. W., Hurles, M. E. Origins and functional impact of copy number variation in the human genome. Nature 464(7289), 2010, pp. 704-712.

28. Cortés-Mendoza, J., Díaz de León-Guerrero, S., Pedraza-Alva, G., Pérez-Martínez, L. Shaping synaptic plasticity: the role of activity-mediated epigenetic regulation on gene transcription. International Journal of Developmental Neuroscience 31(6), 2013, pp. 359-69.

29. Crews, D., Gillette, R., Scarpino, S. V., Manikkam, M., Savenkova, M. I., Skinner, M. K. Epigenetic transgenerational inheritance of altered stress responses. Proceedings of the National Academy of Sciences of the United States of America 109, 2012, pp. 9143-9148. 
30. Curley, J. P., Champagne, F.A. Influence of maternal care on the developing brain: Mechanisms, temporal dynamics and sensitive periods. Frontiers in Neuroendocrinology 40, 2016, pp. 52-66.

31. Dawson, M. A., Kouzarides, T. Cancer epigenetics: from mechanism to therapy. Cell 150(1), 2012, pp. 12-27.

32. Daxinger, L., Whitelaw, E. Transgenerational epigenetic inheritance: More questions than answers. Genome Research 20, 2010, pp. 1623-1628.

33. Daxinger, L., Whitelaw, E. Understanding transgenerational epigenetic inheritance via the gametes in mammals. Nature Reviews Genetics 13, 2012, pp. 153-162.

34. de los Campos, G., Vazquez, A. I., Fernando, R., Klimentidis, Y. C., Sorensen, D. Prediction of complex human traits using the genomic best linear unbiased predictor. PLoS Genetics 9(7), 2013, p. e1003608.

35. Desrivières, S., Lourdusamy, A., Tao, C., Toro, R., Jia, T., Loth, E., Medina, L. M., Kepa, A., Fernandes, A., Ruggeri, B., Carvalho, F. M., Cocks, G., Banaschewski, T., Barker, G. J., Bokde, A. L., Büchel, C., Conrod, P. J., Flor, H., Heinz, A., Gallinat, J., Garavan, H., Gowland, P., Brühl, R., Lawrence, C., Mann, K., Martinot, M. L., Nees, F., Lathrop, M., Poline, J. B., Rietschel, M., Thompson, P., Fauth-Bühler, M., Smolka, M. N., Pausova, Z., Paus, T., Feng, J., Schumann, G. Single nucleotide polymorphism in the neuroplastin locus associates with cortical thickness and intellectual ability in adolescents. Molecular Psychiatry 20(2), 2014, pp. 263-274.

36. Devanna, P., Middelbeek, J., Vernes, S. C. FOXP2 drives neuronal differentiation by interacting with retinoic acid signaling pathways. Frontiers in Cellular Neuroscience 8, 2014, p. 305.

37. Dias, B. G., Maddox, S. A., Klengel, T., Ressler, K. J. Epigenetic mechanisms underlying learning and the inheritance of learned behaviors. Trends in Neuroscience 38(2), 2015, pp. 96-107.

38. Dias, B. G., Ressler, K. J. Parental olfactory experience influences behavior and neural structure in subsequent generations. Nature Neuroscience 17(1), 2014, pp. 89-96.

39. Dick, D. M., Agrawal, A., Keller, M. C., Adkins, A., Aliev, F., Monroe, S., Hewitt, J. K., Kendler, K. S., Sher, K. J. Candidate gene-environment interaction research: reflections and recommendations. Perspectives on Psychological Science: A Journal of the Association for Psychological Science 10(1), 2015, pp. 37-59.

40. Dick, D. M., Bernard, M., Aliev, F., Viken, R., Pulkkinen, L., Kaprio, J., Rose, R. J. The role of socioregional factors in moderating genetic influences on early adolescent behavior problems and alcohol use. Alcoholism: Clinical and Experimental Research 33(10), 2009, pp. 1739-1748.

41. Dietz, D. M., LaPlant, Q., Watts, E. L., Hodes, G. E., Russo, S. J., Feng, J., Oosting, R. S., Vialou, V., Nestler, E. J. Paternal transmission of stress-induced pathologies. Biological Psychiatry 70, 2011, pp. 408-414.

42. Drong, A. W., Lindgren, C. M., McCarthy, M. I. The genetic and epigenetic basis of type 2 diabetes and obesity. Clinical Pharmacology and Therapeutics 92(6), 2012, pp. 707-15.

43. Duncan, L. E., Keller, M. C. A critical review of the first 10 years of candidate gene-byenvironment interaction research in psychiatry. American Journal of Psychiatry 168, 2011, pp. 1041-1049.

44. Egger, G., Liang, G., Aparicio, A., Jones, P. A. Epigenetics in human disease and prospects for epigenetic therapy. Nature 429(6990), 2004, pp. 457-463.

45. Ehrlich, M., Lacey, M. DNA methylation and differentiation: silencing, upregulation and modulation of gene expression. Epigenomics 5, 2013, pp. 553-568.

46. Enattah, N. S., Sahi, T., Savilahti, E., Terwilliger, J. D., Peltonen, L., Järvelä, I. Identification of a variant associated with adult-type hypolactasia. Nature Genetics 30(2), 2002, pp. 233-237.

47. Enattah, N. S., Jensen, T. G., Nielsen, M., Lewinski, R., Kuokkanen, M., Rasinpera, H., ElShanti, H., Seo, J. K., Alifrangis, M., Khalil, I. F., Natah, A., Ali, A., Natah, S., Comas, D., Mehdi, S. Q., Groop, L., Vestergaard, E. M., Imtiaz, F., Rashed, M. S., Meyer, B., Troelsen, J., Peltonen, L. 
Independent introduction of two lactase-persistence alleles into human populations reflects different history of adaptation to milk culture. American Journal of Human Genetics 82(1), 2008, pp. 57-72. 48. English, A. C., Salerno, W. J., Hampton, O. A., Gonzaga-Jauregui, C., Ambreth, S., Ritter, D. I., Beck, C. R., Davis, C. F., Dahdouli, M., Ma, S., Carroll, A., Veeraraghavan, N., Bruestle, J., Drees, B., Hastie, A., Lam, E. T., White, S., Mishra, P., Wang, M., Han, Y., Zhang, F., Stankiewicz, P., Wheeler, D. A., Reid, J. G., Muzny, D. M., Rogers, J., Sabo, A., Worley, K. C., Lupski, J. R., Boerwinkle, E., Gibbs, R. A. Assessing structural variation in a personal genome-towards a human reference diploid genome. BMC Genomics 16, 2015, p. 286.

49. Fagiolini, M., Jensen, C. L., Champagne, F. A. Epigenetic influences on brain development and plasticity. Current Opinion in Neurobiology 19(2), 2009, pp. 207-212.

50. Fass, D. M., Schroeder, F. A., Perlis, R. H., Haggarty, S. J. Epigenetic mechanisms in mood disorders: targeting neuroplasticity. Neuroscience 264, 2014, pp. 112-130.

51. Federman, N., Zalcman, G., de la Fuente, V., Fustiñana, M. S., Romano, A. Epigenetic mechanisms and memory strength: a comparative study. Journal of Physiology, Paris 108(4-6), 2014, pp. 278-85.

52. Feil, R., Fraga, M. Epigenetics and the environment: Emerging patterns and implications. Nature Review Genetics 13(2), 2012, pp. 97-109.

53. Feuk, L., Carson, A. R., Scherer, S. W. Structural variation in the human genome. Nature Reviews. Genetics 7(2), 2006, pp. 85-97.

54. Fischer, A., Sananbenesi, F., Wang, X., Dobbin, M., Tsai, L. H. Recovery of learning and memory is associated with chromatin remodeling. Nature 447(7141), 2007, pp. 178-82.

55. Fisher, S.E. Tangled webs: tracing the connections between genes and cognition. Cognition. 101(2), 2006, pp. 270-97.

56. Fisher, S. E., Scharff, C. FOXP2 as a molecular window into speech and language. Trends in Genetics 25, 2009, pp. 166-177.

57. Fisher, S. E., Vargha-Khadem, F., Watkins, K. E., Monaco, A. P., Pembrey, M. E. Localisation of a gene implicated in a severe speech and language disorder. Nature Genetics 18(2), 1998, pp. 168-170.

58. Flynn, J. R. The mean IQ of Americans: Massive gains 1932 to 1978. Psychological Bulletin 95, 1984, pp. 29-51.

59. Fox-Keller, E. The mirage of a space between nature and nurture. Duke University Press: Durham, NC and London, 2010.

60. Fraga, M. F., Ballesta, E., Paz, M. F., Ropero, S., Setien, F., Ballestar, M. L., Heine-Suñer, D., Cigudosa, J. C., Urioste, M., Benitez, J., Boix-Chornet, M., Sanchez-Aguilera, A., Ling, C., Carlsson, E., Poulsen, P., Vaag, A., Stephan, Z., Spector, T. D., Wu, Y. Z., Plass, C., Esteller, M. Epigenetic differences arise during the lifetime of monozygotic twins. Proceedings of the National Academy of Sciences of the United States of America 102(30), 2005, pp. 10604-10609.

61. Franklin, T. B., Russig, H., Weiss, I. C., Graff, J., Linder, N., Michalon, A. Epigenetic transmission of the impact of early stress across generations. Biological Psychiatry 68, 2010, pp. 408-415.

62. Fu, L., Shi, Z., Luo, G., Tu, W., Wang, X., Fang, Z., Li, X. Multiple microRNAs regulate human FOXP2 gene expression by targeting sequences in its 3' untranslated region. Molecular Brain 7, 2014, p. 71.

63. Fullard, J. F., Halene, T. B., Giambartolomei, C., Haroutunian, V., Akbarian, S., Roussos, P. Understanding the genetic liability to schizophrenia through the neuroepigenome. Schizophrenia Research Jan 27, 2016, pp. S0920-9964(16)30039-1.

64. Galton, F. On men of science, their nature and nurture. In. Notices of the proceedings at the meetings of the members of the Royal Institution of Great Britain. Vol. VII. 1873-1875, William Clowes and Sons: London, 1875. 
65. Gamazon, E. R., Stranger, B. E. The impact of human copy number variation on gene expression. Briefings in Functional Genomics 14(5), 2015, pp. 352-357.

66. Gao, M. C., Bellugi, U., Dai, L., Mills, D. L., Sobel, E. M., Lange, K., Korenberg, J. R. Intelligence in Williams Syndrome is related to STX1A, which encodes a component of the presynaptic SNARE complex. PLoS ONE 5(4), 2010, p. e10292.

67. Gapp, K., Bohacek, J., Grossmann, J., Brunner, A. M., Manuella, F., Nanni, P., Mansuy, I. M. Potential of environmental enrichment to prevent transgenerational effects of paternal trauma. Neuropsychopharmacology Jun 9, 2016.

68. Gerstein, M. B., Bruce, C., Rozowsky, J. S., Zheng, D., Du, J., Korbel, J. O., Emanuelsson, O., Zhang, Z. D., Weissman, S., Snyder M. What is a gene, post-ENCODE? History and updated definition. Genome Research 17(6), 2007, pp. 669-681.

69. Glinsky, G. V. Phenotype-defining functions of multiple non-coding RNA pathways. Cell Cycle 7(11), 2008, pp. 1630-1639.

70. Gluckman, P. D., Hanson M. A. The fetal matrix: Evolution, development, and disease. Cambridge University Press: New York, 2005.

71. Gräff, J., Mansuy, I. M. Epigenetic codes in cognition and behavior. Behavioural Brain Research 192(1), 2008, pp. 70-87.

72. Gravlee, C. C. How race becomes biology: Embodiment of social inequality. American Journal of Physical Anthropology 139, 2009, pp. 47-57.

73. Greiffenstein, M. F. Secular IQ increases by epigenesis? The hypothesis of cognitive genotype optimization. Psychological Reports 109(2), 2011, pp. 353-366.

74. Griffiths, B. B., Hunter, R. G. Neuroepigenetics of stress. Neuroscience 275, 2014, pp. 420435.

75. Grossniklaus, U., Kelly, W. G., Ferguson-Smith, A. C., Pembrey, M., Lindquist, S. Transgenerational epigenetic inheritance: How important is it? Nature Reviews Genetics 14(11), 2013, pp. 228-235.

76. Gudbjartsson, D. F., Walters, G. B., Thorleifsson, G., Stefansson, H., Halldorsson, B. V., Zusmanovich, P., Sulem, P., Thorlacius, S., Gylfason, A., Steinberg, S., Helgadottir, A., Ingason, A., Steinthorsdottir, V., Olafsdottir, E. J., Olafsdottir, G. H., Jonsson, T., Borch-Johnsen, K., Hansen, T., Andersen, G., Jorgensen, T., Pedersen, O., Aben, K. K., Witjes, J. A., Swinkels, D. W., den Heijer, M., Franke, B., Verbeek, A. L., Becker, D. M., Yanek, L. R., Becker, L. C., Tryggvadottir, L., Rafnar, T., Gulcher, J., Kiemeney, L. A., Kong, A., Thorsteinsdottir, U., Stefansson, K. Many sequence variants affecting diversity of adult human height. Nature Genetics 40, 2008, pp. 609-615.

77. Gupta-Agarwal, S., Jarome, T. J., Fernandez, J., Lubin, F. D. NMDA receptor- and ERKdependent histone methylation changes in the lateral amygdala bidirectionally regulate fear memory formation. Learning \& Memory 21(7), 2014, pp. 351-362.

78. Hamatani, T. Human spermatozoal RNAs. Fertility and Sterility 97, 2012, pp. 275-281.

79. Haraksingh, R. R., Snyder, M. P. Impacts of variation in the human genome on gene regulation. Journal of Molecular Biology 425(21), 2013, pp. 3970-3977.

80. Harden, K. P., Hill, J. E., Turkheimer, E., Emery, R. E. Gene-environment correlation and interaction in peer effects on adolescent alcohol and tobacco use. Behavior Genetics 38, 2008, pp. 339-347.

81. Heard, E., Martienssen, R. A. Transgenerational Epigenetic Inheritance: Myths and Mechanisms. Cell 157, 2014, pp. 95-109.

82. Heijmans, B. T., Tobi, E. W., Stein, A. D., Putter, H., Blauw, G. J., Susser, E. S., Slagboom, P. E., Lumey, L. H. Persistent epigenetic differences associated with prenatal exposure to famine in humans. Proceedings of the National Academy of Sciences USA 105, 2008, pp. 17046-17049.

83. Heinzelmann, M., Gill, J. Epigenetic mechanisms shape the biological response to trauma and risk for PTSD: A critical review. Nursing Research and Practice 2013, 2013, p. 417010. 
84. Hiemstra, M., Kleinjan, M., van Schayck, O. C., Engels, R. C., Otten, R. Environmental smoking and smoking onset in adolescence: the role of dopamine-related genes. Findings from two longitudinal studies. PLoS One 9(1), 2014, p. e86497.

85. Hindorff, L. A, Sethupathy, P., Junkins, H. A., Ramos, E. M., Mehta, J. P., Collins, F. S., Manolio, T. A. Potential etiologic and functional implications of genome-wide association loci for human diseases and traits. Proceedings of the National Academy of Sciences of the United States of America 106(23), 2009, pp. 9362-9367.

86. Imamura, T., Uesaka, M., Nakashima, K. Epigenetic setting and reprogramming for neural cell fate determination and differentiation. Philosophical Transactions of the Royal Society of London. Series B, Biological Sciences 369(1652), 2014.

87. Jablonka, E. Epigenetic variations in heredity and evolution. Clinical Pharmacology and Therapeutics 92(6), 2012, pp. 683-688.

88. Jablonka, J., Raz, G. Transgenerational epigenetic inheritance: Prevalence, mechanisms, and implications for the study of heredity and evolution. Quarterly Review of Biology 84, 2009, pp. 131-176.

89. Jarome, T. J., Butler, A. A., Nichols, J. N., Pacheco, N. L., Lubin, F. D. NF-кB mediates Gadd $45 \beta$ expression and DNA demethylation in the hippocampus during fear memory formation. Frontiers in Molecular Neuroscience 8, 2015, pp. 54.

90. Jarome, T. J., Thomas, J. S., Lubin, F. D. The epigenetic basis of memory formation and storage. Progress in Molecular Biology and Translational Science 28, 2014, pp. 1-27.

91. Jia, Y., Chen, L., Ma, Y., Zhang, J., Xu, N., Liao, D.J. To know how a gene works, we need to redefine it first but then, more importantly, to let the cell itself decide how to transcribe and process its RNAs. International Journal of Biological Sciences 11(12), 2015, pp. 1413-1423.

92. Jirtle, R. L., Skinner, M. K. Environmental epigenomics and disease susceptibility. Nature Reviews Genetics 8, pp. 253-262.

93. Johnson, G. D., Lalancette, C., Linnemann, A. K., Leduc, F., Boissonneault, G., Krawetz, S. A. The sperm nucleus: Chromatin, RNA, and the nuclear matrix. Reproduction 141, 2011, pp. 21-36.

94. Kaati, G., Bygren, L. O., Pembrey, M., Sjostrom, M. Transgenerational response to nutrition, early life circumstances and longevity. European Journal of Human Genetics 15(7), pp. 784-790.

95. Kahrer-Sawatzki, H. What a difference copy number variation makes. Bioessays 29(4), 2007 , pp. 311-313.

96. Kellermann, N. P. Epigenetic transmission of holocaust trauma: can nightmares be inherited? The Israel Journal of Psychiatry and Related Sciences 50(1), 2013, pp. 33-39.

97. Keverne, E. B., Curley, J. P. Epigenetics, brain evolution and behavior. Frontiers in Neuroendocrinology 29(3), 2008, pp. 398-412.

98. Kevles, D. J. In the name of eugenics: Genetics and the uses of human heredity. Harvard University Press: Cambridge, MA, 1985.

99. Kim, D. H., Saetrom, P., Snove, O., Jr., Rossi, J. J. MicroRNA-directed transcriptional gene silencing in mammalian cells. Proceedings of the National Academy of Sciences of the United States of America 105, 2-8, pp. 16230-16235.

100. Kingsley, D. M. From atoms to traits. Scientific American 300(1), 2009, pp. 52-59.

101. Krawetz, S. A. Paternal contribution: New insights and future challenges. Nature Reviews Genetics 6, 2005, pp. 633-642.

102. Krawetz, S. A., Kruger, A., Lalancette, C., Tagett, R., Anton, E., Draghici, S., et al. A survey of small RNAs in human sperm. Human Reproduction 26, 2011, pp. 3401-3412.

103. Kubota ,T., Mochizuki, K. Epigenetic effect of environmental factors on autism spectrum disorders. International Journal of Environmental Research and Public Health 13(5), 2016, p. E504.

104. Kuokkanen, M., Kokkonen, J., Enattah, N. S., Ylisaukko-oja, T., Komu, H., Varilo, T., Peltonen, L., Savilahti, E., Jarvela, I. Mutations in the translated region of the lactase gene (LCT) 
underlie congenital lactase deficiency. American Journal of Human Genetics 78(2), 2006, pp. 339344.

105. Kuzawa, C., Sweet, E. Epigenetics and the embodiment of race: Developmental origins of US racial disparities in cardiovascular health. American Journal of Human Biology 21, 2009, pp. 2-15.

106. Labonté, B., Suderman, M., Maussion, G., Navaro, L., Yerko, V., Mahar, I., Bureau, A., Mechawar, N., Szyf, M., Meaney, M. J., Turecki, G. Genome-wide epigenetic regulation by earlylife trauma. Archives of General Psychiatry 69(7), 2012, pp. 722-731.

107. Lander, E. S. Initial impact of the sequencing of the human genome. Nature 470(7333), 2011, pp. 187-197.

108. Lander, E. S., Linton, L. M., Birren, B., Nusbaum, C., Zody, M. C., Baldwin, J., Devon, K., Dewar, K., Doyle, M., FitzHugh, W., Funke, R., Gage, D., Harris, K., Heaford, A., Howland, J., Kann, L., Lehoczky, J., LeVine, R., McEwan, P., McKernan, K., Meldrim, J., Mesirov, J. P., Miranda, C., Morris, W., Naylor, J., Raymond, C., Rosetti, M., Santos, R., Sheridan, A., Sougnez, C., Stange-Thomann, Y., Stojanovic, N., Subramanian, A., Wyman, D., Rogers, J., Sulston, J., Ainscough, R., Beck, S., Bentley, D., Burton, J., Clee, C., Carter, N., Szustakowki, J., et al., International Human Genome Sequencing Consortium. Initial sequencing and analysis of the human genome. Nature 409(6822), 2001, pp. 860-921. Erratum in: Nature 411(6838), 2001, pp. 720. Szustakowki, J. [corrected to Szustakowski, J]. Nature 412(6846), 2001, p. 565.

109. Leen-Feldner, E. W., Feldner, M. T., Knapp, A,, Bunaciu, L., Blumenthal, H., Amstadter, A.B. Offspring psychological and biological correlates of parental posttraumatic stress: review of the literature and research agenda. Clinical Psychology Review 33(8), 2013, pp. 1106-1133.

110. Lettre, G., Jackson, A. U., Gieger, C., Schumacher, F. R., Berndt, S. I., Sanna, S., Eyheramendy, S., Voight, B. F., Butler, J. L., Guiducci, C., Illig, T., Hackett, R., Heid, I. M., Jacobs, K. B., Lyssenko, V., Uda, M., et al. Identification of ten loci associated with height highlights new biological pathways in human growth. Nature Genetics 40, 2008, pp. 584-591.

111. Levy, Y., Ebstein, R. P. Research review: crossing syndrome boundaries in the search for brain endophenotypes. Journal of Child Psychology and Psychiatry, and Allied Disciplines 50(6), 2009, pp. 657-668.

112. Liebers, R., Rassoulzadegan, M., Lyko, F. Epigenetic regulation by heritable RNA. PLoS Genetics 10(4), 2014, p. e1004296.

113. Liegeois, F., Baldeweg, T., Connelly, A., Gadian, D. G., Mishkin, M., Vargha-Khadem, F. Language fMRI abnormalities associated with FOXP2 gene mutation. Nature Neuroscience 6(11), 2003, pp. 1230-1237.

114. Lim, J. P., Brunet, A. Bridging the transgenerational gap with epigenetic memory. Trends in Genetics 29(3), 2013, pp. 176-186.

115. Liu, N., Pan, T. RNA epigenetics. Translational Research: The Journal of Laboratory and Clinical Medicine 165(1), 2015, pp. 28-35.

116. Lock, M. The epigenome and nature/nurture reunification: a challenge for anthropology. Medical Anthropology 32(4), 2013, pp. 291-308.

117. Locke, J. Some Thoughts Concerning Education: Full and Fine 1693 Edition (Illustrated) Kindle Edition. www.WealthOfNation.com, 2014.

118. Maccari, S., Krugers, H. J., Morley-Fletcher, S., Szyf, M., Brunton, P. J. The consequences of early-life adversity: neurobiological, behavioural and epigenetic adaptations. Journal of Neuroendocrinology 26(10), 2014, pp. 707-723.

119. Maher, B. Personal genomes: The case of the missing heritability. Nature 456(7218), 2008, pp. 18-21.

120. Makowsky, R., Pajewski, N. M., Klimentidis, Y. C., Vazquez, A. I., Duarte, C. W., Allison, D. B., de los Campos, G. Beyond Missing Heritability: Prediction of Complex Traits. PLoS Genetics 7, 2011, p. e1002051. 
121. Manolio, T. A., Collins, F. S., Cox, N. J., Goldstein, D. B., Hindorff, L. A., Hunter, D. J., McCarthy, M. I., Ramos, E. M., Cardon, L. R., Chakravarti, A., Cho, J. H., Guttmacher, A. E., Kong, A., Kruglyak, L., Mardis, E., Rotimi, C. N., Slatkin, M., Valle, D., Whittemore, A. S., Boehnke, M., Clark, A. G., Eichler, E. E., Gibson, G., Haines, J. L., Mackay, T.F., McCarroll, S. A., Visscher, P. M. Finding the missing heritability of complex diseases. Nature 461, 2009, pp. 747-753.

122. Mansuy, I. M., Mohanna, S. Epigenetics and the human brain: where nurture meets nature. Cerebrum 2011 May, 2011, p. 8.

123. Marcus, G. F., Fisher, S. E. FOXP2 in focus: what can genes tell us about speech and language? Trends in Cognitive Science 7(6), 2003, pp. 257-262.

124. Marian, A. J. Molecular genetic studies of complex phenotypes. Translational Research: The Journal of Laboratory and Clinical Medicine 159(2), 2012, pp. 64-79.

125.Marino, C., Mascheretti, S., Riva, V., Cattaneo, F., Rigoletto, C., Rusconi, M., Gruen, J. R., Giorda, R., Lazazzera, C., Molteni, M. Pleiotropic effects of DCDC2 and DYX1C1 genes on language and mathematics traits in nuclear families of developmental dyslexia. Behavior Genetics 41(1), 2011, pp. 67-76.

126. Mascheretti, S., Riva, V., Giorda, R., Beri, S., Lanzoni, L. F., Cellino, M. R., Marino, C. KIAA0319 and ROBO1: evidence on association with reading and pleiotropic effects on language and mathematics abilities in developmental dyslexia. Journal of Human Genetics 59(4), 2014, pp. 189-197.

127. McGowan, P. O., Szyf, M. The epigenetics of social adversity in early life: implications for mental health outcomes. Neurobiology of Disease 39(1), 2010, pp. 66-72.

128. Meloni, M., Testa, G. Scrutinizing the epigenetics revolution. Biosocieties 9(4), 2014, pp. 431456.

129. Miller, G. The seductive allure of behavioral epigenetics. Science 329, 2010, pp. 24-27.

130. Mitchell, E., Klein, S. L., Argyropoulos, K. V., Sharma, A., Chan, R. B., Toth, J. G., Barboza, L., Bavley, C., Bortolozzi, A., Chen, Q., Liu, B., Ingenito, J., Mark, W., Dudakov, J., Gross, S., Di Paolo, G., Artigas, F., van den Brink, M., Toth, M. Behavioural traits propagate across generations via segregated iterative-somatic and gametic epigenetic mechanisms. Nature Communications 7 , 2016, p. 11492.

131. Monsey, M. S., Ota, K. T., Akingbade, I. F., Hong, E. S., Schafe, G. E. Epigenetic alterations are critical for fear memory consolidation and synaptic plasticity in the lateral amygdale. PLoS One 6(5), 2011, p. e19958.

132. Morris, K. V. Chan, S.W.-L., Jacobsen, S.E., Looney, D.J. Small interfering RNA-induced transcriptional gene silencing in human cells. Science 305, 2004, pp. 1289-1292.

133. Mozzi, A., Forni, D., Clerici, M., Pozzoli, U., Mascheretti, S., Guerini, F. R., Riva, S., Bresolin, N., Cagliani, R., Sironi, M. The evolutionary history of genes involved in spoken and written language: beyond FOXP2. Scientific Reports 6, 2016, p. 22157.

134. Mukamel, Z., Konopka, G., Wexler, E., Osborn, G. E., Dong, H., Bergman, M. Y., Levitt, P., Geschwind, D. H. Regulation of MET by FOXP2, genes implicated in higher cognitive dysfunction and autism risk. Journal of Neuroscience 31(32), 2011, pp. 11437-11442.

135. Nagy, C., Turecki, G. Transgenerational epigenetic inheritance: an open discussion. Epigenomics 7(5), 2015, pp. 781-790.

136. Naumova, O. Y., Lee, M., Koposov, R., Szyf, M., Dozier, M., Grigorenko, E. L. Differential patterns of whole-genome DNA methylation in institutionalized children and children raised by their biological parents", Development and Psychopathology 24(1), 2012, 143-155.

137. Nestler, E. J. Transgenerational epigenetic contributions to stress responses: fact or fiction? PLoS Biology 14(3), 2016, p. e1002426 (Correction: PLoS Biology 14(6), 2016, p. e1002486).

138. Newbury, D. F., Winchester, L., Addis, L., Paracchini, S., Buckingham, L. L., Clark, A., Cohen, W., Cowie, H., Dworzynski, K., Everitt, A., Goodyer, I. M., Hennessy, E., Kindley, A. D., 
Miller, L. L., Nasir, J., O'Hare, A., Shaw, D., Simkin, Z., Simonoff, E., Slonims, V., Watson, J., Ragoussis, J., Fisher, S. E., Seckl, J. R., Helms, P. J., Bolton, P. F., Pickles, A., Conti-Ramsden, G., Baird, G., Bishop, D. V., Monaco, A. P. CMIP and ATP2C2 modulate phonological short-term memory in language impairment._American Journal of Human Genetics 85(2), 2009, pp. 264-272.

139. Nilsson, E. E., Skinner, M. K. Environmentally induced epigenetic transgenerational inheritance of disease susceptibility. Translational Research: The Journal of Laboratory and Clinical Medicine 165(1), 2015, pp. 12-17.

140. Olfson, E., Edenberg, H. J., Nurnberger, J., Jr., Agrawal, A., Bucholz, K. K., Almasy, L. A., Chorlian, D., Dick, D. M., Hesselbrock, V. M., Kramer, J. R., Kuperman, S., Porjesz, B., Schuckit, M. A., Tischfield, J. A., Wang, J. C., Wetherill, L., Foroud, T. M., Rice, J., Goate, A., Bierut, L. J. An ADH1B variant and peer drinking in progression to adolescent drinking milestones: evidence of a gene-by-environment interaction. Alcoholism: Clinical and Experimental Research 38(10), 2014, pp. 2541-2549.

141. Painter, R., Osmond, C., Gluckman, P., Hanson, M., Phillips, D., Roseboom, T. J. Transgenerational effects of prenatal exposure to the Dutch famine on neonatal adiposity and health in later life. BJOG: An International Journal of Obstetrics and Gynaecology 115, 2008, pp. 12431249.

142. Paracchini, S. Dissection of genetic associations with language-related traits in populationbased cohorts. Journal of Neurodevelopmental Disorders 3, 2011, pp. 365-373.

143.Pearson, H. Genetics: what is a gene? Nature 441(7092), 2006, pp. 398-401.

144. Peixoto, L., Abel, T. The role of histone acetylation in memory formation and cognitive impairments. Neuropsychopharmacology 38(1), 2013, pp. 62-76.

145. Pennisi, E. Genomics. ENCODE project writes eulogy for junk DNA. Science 337(6099), pp. 1159-1161.

146. Perera, F., Herbstman, J. Prenatal environmental exposures, epigenetics, and disease. Reproductive Toxicology 31(3), 2011, pp. 363-373.

147. Perroud, N., Rutembesa, E., Paoloni-Giacobino, A., Mutabaruka, J., Mutesa, L., Stenz, L., et al. The Tutsi genocide and transgenerational transmission of maternal stress: epigenetics and biology of the HPA axis. The World Journal of Biological Psychiatry: the Official Journal of the World Federation of Societies of Biological Psychiatry 15(4), 2014, pp. 334-345.

148. Perry, G. H., Dominy, N. J., Claw, K. G., Lee, A. S., Fiegler, H., Redon, R., Werner, J., Villanea, F. A., Mountain, J. L., Misra, R., Carter, N. P., Lee, C., Stone, A. C. Diet and the evolution of human amylase gene copy number variation. Nature Genetics 39(10), 2007, pp. 12561260.

149. Pietschnig, .J, Voracek, M., Formann, A. K. Pervasiveness of the IQ rise: a cross-temporal meta-analysis. PLoS One 5(12), 2010, p. e14406.

150. Plomin, R., DeFries, J. C., Knopik, V. S., Neiderhiser, J. M. Top 10 replicated findings from behavioral genetics. Perspectives on Psychological Science 11, 2016, pp. 3-23.

151. Plomin, R., DeFries, J. C., McClearn, G. E., McGuffin, P. Behavioral genetics. Worth Publishers: New York, 2001.

152. Plomin, R., Kovas, Y. Generalist genes and learning disabilities. Psychological Bulletin 131, 2005, pp. 592-617.

153. Przeworski, M., Hudson, R. R., Di Rienzo, A. Adjusting the focus on human variation. Trends in Genetics 16(7), 2000, pp. 296-302.

154. Qureshi, I. A., Mehler, M. F. An evolving view of epigenetic complexity in the brain. Philosophical Transactions of the Royal Society of London. Series B, Biological Sciences 369(1652), 2014.

155. Radtke, K. M., Ruf, M., Gunter, H. M., Dohrmann, K., Schauer, M., Meyer, A., Elbert, T. Transgenerational impact of intimate partner violence on methylation in the promoter of the glucocorticoid receptor. Translational Psychiatry 1, 2011, p. e21. 
156. Radtke, K. M., Schauer, M., Gunter, H. M., Ruf-Leuschner, M., Sill, J., Meyer, A., Elbert, T. Epigenetic modifications of the glucocorticoid receptor gene are associated with the vulnerability to psychopathology in childhood maltreatment. Translational Psychiatry 5, 2015, p. e571.

157. Reich, D. E., Schaffner, S. F., Daly, M. J., McVean, G., Mullikin, J. C., Higgins, J. M., Richter, D. J., Lander, E. S., Altshuler, D. Human genome sequence variation and the influence of gene history, mutation and recombination. Nature Genetics 32(1), 2002, pp. 135-142.

158. Richards, E. J. Inherited epigenetic variation - revisiting soft inheritance. Nature Reviews Genetics 7, 2006, pp. 395-401.

159. Richardson, Sarah S. Maternal bodies in the postgenomic order: Gender and the explanatory landscape of epigenetics. In. Richardson S. S., Stevens H. (eds.). Postgenomics: Perspectives on biology after the genome. Duke University Press, 2015

160. Richardson, Sarah S., Daniels, C. R., Gillman, M. W., Golden, J., Kukla, R., Kuzawa, Ch., Rich-Edwards, J. Don't blame the mothers. Nature 512, 2014, pp. 131-132.

161. Rietveld, C. A., Esko, T., Davies, G., Pers, T. H., Turley, P., Benyamin, B., Chabris, C. F., Emilsson, V., Johnson, A. D., Lee, J. J., de Leeuw, C., Marioni, R. E., Medland, S. E., Miller, M. B., Rostapshova, O., van der Lee, S. J., Vinkhuyzen, A. A., Amin, N., Conley, D., Derringer, J., van Duijn, C. M., Fehrmann, R., Franke, L., Glaeser, E. L., et al. Common genetic variants associated with cognitive performance identified using the proxy-phenotype method. Proceedings of the National Academy of Sciences of the United States of America 111(38), 2014, pp. 13790-13794.

162. Rivera, C. M., Ren, B. Mapping human epigenomes. Cell 155, 2013, pp. 39-55.

163. Roberts, T. C., Morris, K. V., Wood, M. J. The role of long non-coding RNAs in neurodevelopment, brain function and neurological disease. Philosophical Transactions of the Royal Society of London. Series B, Biological Sciences 369(1652), 2014.

164. Rodgers, A. B, Bale, T. L. Germ cell origins of posttraumatic stress disorder risk: the transgenerational impact of parental stress experience. Biological Psychiatry 78(5), 2015, pp. 307314.

165. Rodgers, A. B, Morgan, C. P., Leu, N. A., Bale, T. L. Transgenerational epigenetic programming via sperm microRNA recapitulates effects of paternal stress. Proceedings of the National Academy of Sciences of the United States of America 112(44), 2015, pp. 13699-13704.

166. Rose, N. R., Klose, R. J. Understanding the relationship between DNA methylation and histone lysine methylation. Biochimica et Biophysica Acta 1839(12), 2014, pp. 1362-72.

167. Roseboom, T., de Rooij, S. Painter, R. The Dutch famine and its long-term consequences for adult health. Early Human Development 82(8), 2006, pp. 485-491.

168. Rutter, M., Moffitt, T. E., Caspi, A. Gene-environment interplay and psychopathology: multiple varieties but real effects. Journal of Child Psychology and Psychiatry, and Allied Disciplines 47(3-4), 2006, pp. 226-61.

169. Ruzicka, W. B. Epigenetic mechanisms in the pathophysiology of psychotic disorders. Harvard Review of Psychiatry 23(3), 2015, pp. 212-222.

170. Sapolsky, R. M. Mothering style and methylation. Nature Neuroscience 7(8), 2004, pp. 791792.

171. Scerri, T. S., Morris, A. P., Buckingham, L. L., Newbury, D. F., Miller, L. L., Monaco, A. P., Bishop, D.V ., Paracchini, S. DCDC2, KIAA0319 and CMIP are associated with reading-related traits. Biological Psychiatry 70(3), 2011, pp. 237-245.

172. Schubert, C. The genomic basis of the Williams-Beuren syndrome. Cellular and Molecular Life Sciences 66(7), 2009, pp. 1178-1197.

173. Shen, E., Shulha, H., Weng, Z., Akbarian, S. Regulation of histone H3K4 methylation in brain development and disease. Philosophical Transactions of the Royal Society of London. Series B, Biological Sciences 369 (1652), 2014.

174. Sherry, S. T., Ward, M. H., Kholodov, M., Baker, J., Phan, L., Smigielski, E. M., Sirotkin, K. dbSNP: the NCBI database of genetic variation. Nucleic Acid Research 29, 2001, pp. 308-311. 
175. Simmons, J. P., Nelson, L. D., Simonsohn, U. False-positive psychology: undisclosed flexibility in data collection and analysis allows presenting anything as significant. Psychological Science 22(11), 2011, pp.1359-1366.

176. Simpson, J., Kelly, J. P. The impact of environmental enrichment in laboratory rats: Behavioural and neurochemical aspects. Behavioural Brain Research 222, 2011, pp. 246-264.

177. Skinner, M. K. Endocrine disruptor induction of epigenetic transgenerational inheritance of disease. Molecular and Cellular Endocrinology 398(1-2), 2014, pp. 4-12.

178. Skinner, M. K. Environmental Epigenetics and a Unified Theory of the Molecular Aspects of Evolution: A Neo-Lamarckian concept that facilitates neo-Darwinian evolution. Genome Biology and Evolution 7(5), 2015, pp. 1296-302.

179. Skinner, M. K. Environmental stress and epigenetic transgenerational inheritance. $B M C$ Medicine 12, 2014, p. 153.

180. Skinner, M. K., Anway, M. D., Savenkova, M. I., Gore, A. C., Crews, D. Transgenerational epigenetic programming of the brain transcriptome and anxiety behavior. PLoS One 3, 2008, p. e3745.

181. South, S. C., Krueger, R. F., Johnson, W., Iacono, W. G. Adolescent personality moderates genetic and environmental influences on relationships with parents. Journal of Personality and Social Psychology 94(5), 2008, pp. 899-912.

182. Spiteri, E., Konopka, G., Coppola, G., Bomar, J., Oldham, M., Ou, J., Vernes, S. C., Fisher, S. E., Ren, B., Geschwind, D. H. Identification of the transcriptional targets of FOXP2, a gene linked to speech and language, in developing human brain. American Journal of Human Genetics 81(6), 2007, pp. 1144-1157.

183. Suderman, M., Borghol, N., Pappas, J. J., Pinto Pereira, S. M., Pembrey, M., Hertzman, C., Power, C., Szyf, M. Childhood abuse is associated with methylation of multiple loci in adult DNA. BMC Medical Genomics 7, 2014, p. 13.

184. Szyf, M. DNA methylation, behavior and early life adversity. Journal of Genetics and Genomics 40(7), 2013, pp. 331-338.

185. Szyf, M. Lamarck revisited: epigenetic inheritance of ancestral odor fear conditioning. Nature Neuroscience 17(1), 2014, pp. 2-4.

186. Szyf, M. The early-life social environment and DNA methylation. Clinical Genetics 81(4), 2012, pp. 341-349.

187. Szyf, M., Bick, J. DNA methylation: a mechanism for embedding early life experiences in the genome. Child Development 84(1), 2013, pp. 49-57.

188. Szyf, M., Weaver, I., Meaney, M. Maternal care, the epigenome and phenotypic differences in behavior. Reproductive Toxicology 24(1), 2007, pp. 9-19.

189. Toth, M. Mechanisms of non-genetic inheritance and psychiatric disorders. Neuropsychopharmacology 40(1), 2015, pp. 129-140.

190. Trahan, L. H., Stuebing, K. K., Fletcher, J. M., Hiscock, M. The Flynn effect: a meta-analysis. Psychological Bulletin 140(5), 2014, pp. 1332-1360.

191. Trerotola, M., Relli, V., Simeone, P., Alberti, S. Epigenetic inheritance and the missing heritability. Human Genomics 9, 2015, p. 17.

192. Trzaskowski, M., Dale, P. S., Plomin, R. No genetic influence for childhood behavior problems from DNA analysis. Journal of the American Academy of Child and Adolescent Psychiatry 52, 2013, pp.1048-1056.

193. Trzaskowski, M., Davis, O. S., DeFries, J. C., Yang, J., Visscher, P. M., Plomin, R. DNA evidence for strong genome-wide pleiotropy of cognitive and learning abilities. Behavior Genetics 43(4), 2013, pp. 267-73.

194. Tuddenham, R. D. Soldier intelligence in world wars I and II. American Psychologist 3, 1948, pp. 54-56. 
195. Turkheimer, E. Spinach and ice cream: Why social science is so difficult. In. DiLalla, L. (ed.). Behavior genetics principles: Perspectives in development, personality, and psychopathology. American Psychological Association: Washington DC, 2004.

196. Usher, C. L., McCarroll, S. A. Complex and multi-allelic copy number variation in human disease. Briefings in Functional Genomics 14(5), 2015, pp. 329-338.

197. Venter, J. C., Adams, M. D., Myers, E. W., Li, P. W., Mural, R. J., Sutton, G. G., Smith, H. O., Yandell, M., Evans, C. A., Holt, R. A., Gocayne, J. D., Amanatides, P., Ballew, R. M., Huson, D. H., Wortman, J. R., Zhang, Q., Kodira, C. D., Zheng, X. H., Chen, L., Skupski, M., Subramanian, G., Thomas, P. D., Zhang, J., et al. The sequence of the human genome. Science 291(5507), 2001, pp. 1304-1351. Erratum in: Science 292(5523), 2001, p. 1838.

198. Vernes, S. C., Newbury, D. F., Abrahams, B. S., Winchester, L., Nicod, J., Groszer, M., Alarcon, M., Oliver, P. L., Davies, K. E., Geschwind, D. H., Monaco, A. P., Fisher, S. E. A functional genetic link between distinct developmental language disorders. The New England Journal of Medicine 359(22), 2008, pp. 2337-2345.

199. Waggoner, M. R., Tobias, U. Epigenetic determinism in science and society. New Genetics and Society 34:2, 2015, pp. 177-195.

200. Weaver, I. C., Cervoni, N., Champagne, F. A., D'Alessio, A. C., Sharma, S., Seckl, J. R., Dymov, S., Szyf, M., Meaney, M. J. Epigenetic programming by maternal behavior. Nature Neuroscience 7(8), 2004, pp. 847-854.

201. Weber-Stadlbauer, U., Richetto, J., Labouesse, M. A., Bohacek, J., Mansuy, I. M., Meyer, U. Transgenerational transmission and modification of pathological traits induced by prenatal immune activation. Molecular Psychiatry Mar 29, 2016.

202. Weedon, M. N., Lango, H., Lindgren, C. M., Wallace, C., Evans, D. M., Mangino, M., Freathy, R. M., Perry, J. R., Stevens, S., Hall, A. S., Samani, N. J., Shields, B., Prokopenko, I., Farrall, M., Dominiczak, A., et al. Genome-wide association analysis identifies 20 loci that influence adult height. Nature Genetics 40, 2008, pp. 575-583.

203. Wei, Y., Schatten, H., Sun, Q. Y. Environmental epigenetic inheritance through gametes and implications for human reproduction. Human Reproduction Update 21(2), 2015, pp. 194-208.

204. Weiss, I. C., Franklin, T. B., Vizi, S., Mansuy, I. M. Inheritable effect of unpredictable maternal separation on behavioral responses in mice. Frontiers in Behavioral Neuroscience 5, 2011, p. 3.

205. Welter, D., MacArthur, J., Morales, J., Burdett, T., Hall, P., Junkins, H., Klemm, A., Flicek, P., Manolio, T., Hindorff, L., Parkinson, H. The NHGRI GWAS Catalog, a curated resource of SNP-trait associations. Nucleic Acids Research 42 (Database issue), 2014, pp. D1001-D1006.

206. West-Eberhard, M. J. Are genes good markers of biological traits? In. Weinstein, M., Vaupel, J. W., Wachter, K. W. (eds.). Biosocial Surveys. The National Academies Press: Washington DC, 2008.

207. Wolstenholme, J. T., Edwards, M., Shetty, S. R. J., Gatewood, J. D., Taylor, J. A., Rissman, E. F., et al. Gestational exposure to bisphenol a produces transgenerational changes in behaviors and gene expression. Endocrinology 153, 2012, pp. 3828-3838.

208. Yahyavi, S. T., Zarghami, M., Marwah, U. A review on the evidence of transgenerational transmission of posttraumatic stress disorder vulnerability. Revista Brasileira de Psiquiatria: Orgão Oficial da Associação Brasileira de Psiquiatria, Asociación Psiquiátrica de la América Latina 36(1), 2014, pp. 89-94.

209. Yan, W. Potential roles of noncoding RNAs in environmental epigenetic transgenerational inheritance. Molecular and Cellular Endocrinology 398(1-2), 2014, pp. 24-30.

210. Yang, J., Benyamin, B., McEvoy, B. P., Gordon, S., Henders, A. K., Nyholt, D. R., Madden, P. A., Heath, A. C., Martin, N. G., Montgomery, G. W., Goddard, M. E., Visscher, P. M. Common SNPs explain a large proportion of the heritability for human height. Nature Genetics 42, 2010, pp. 565-569. 
211. Yehuda, R., Daskalakis, N. P., Lehrner, A., Desarnaud, F., Bader, H. N., Makotkine, I., Flory, J. D., Bierer, L. M., Meaney, M. J. Influences of maternal and paternal PTSD on epigenetic regulation of the glucocorticoid receptor gene in Holocaust survivor offspring. The American Journal of Psychiatry 171(8), 2014, pp. 872-880.

212. Zhang, F., Lupski, J. R. Non-coding genetic variants in human disease. Human Molecular Genetics 24 (R1), 2015, pp. R102-R110.

213. Zheng, G., Dahl, J. A., Niu, Y., Fu, Y., Klungland, A., Yang, Y. G., He, C. Sprouts of RNA epigenetics. RNA Biology 10(6), 2013, pp. 915-918.

214. Zuk, O., Hechter, E., Sunyaev, S. R., Lander, E. S. The mystery of missing heritability: Genetic interactions create phantom heritability. Proceedings of the National Academy of Sciences of the United States of America 109, 2012, pp. 1193-1198.

\section{Notes}

1. See for example $[64,98]$.

2. "Recently, a fashion has arisen for tracing the phrase 'nature and nurture,' and the debate with which that phrase is associated, back to Shakespeare, or at least to Prospero in The Tempest (1623), who writes off Caliban as uneducable: 'a born devil, on whose nature / nurture will never stick.' Some have traced it further back to a monograph on children's education written by an Elizabethan pedagogue, Richard Mulcaster. Mulcaster's words, 'Nature makes the boy toward, nurture sees him forward' $(1581,35)$, are sometimes cited as an early contribution, and perhaps even a beginning, of 'the great war'" [59, p. 17].

3. Fox-Keller further explains her statement: "I want to suggest that there is already in Darwin's dissent from Mill a clear hint of the turn that Galton makes explicit. This turn, I claim, is rooted in changing conceptions of heredity, and in accord with these changes, with the new alignment between innate and hereditary then taking place. I am not persuaded that there is anything in Mill's writings to indicate such an equation between innate and hereditary, still less to support an equation between nature and heredity. In fact, in many of Mill's remarks, hereditary refers primarily to the inheritance of property or title; as for most writers of his time, the noun heredity was not yet part of his usual vocabulary" [59, p. 21].

4. West-Eberhard MJ. (2008), Are Genes Good Markers of Biological Traits?, p. 178. She adds: "Some authors use the term "module" to describe a discrete trait. In operational terms, a discrete or modular trait can be defined as a product of a separate developmental pathway. But it is more accurate to say that a trait is "somewhat discrete" rather than "discrete," or that it is "modular" rather than "a module" because no trait is completely independent of all other traits in an integrated individual organism" (ibidem).

5. The genetic variation among humans has been estimated by genomic studies, and according to Marian A.J. "humans are genetically very diverse. They differ in approximately $0.1 \%$ of their genomes." [124, p. 65]. These data can be viewed quite differently, however. Feuk L., Carson A.R. \& Scherer S.W. present a different interpretation, stating: "A striking observation from the analysis of the human genome is the extent of DNA-sequence similarity among individuals from around the world: any two humans are thought to be about $99.9 \%$ identical in their DNA sequence. It is therefore through studies of a small fraction of the genome - which constitutes the genetic variation between individuals - that insights into phenotypic variation and disease susceptibility can be gained" [53, p. 85]. It is also suggested that a substantial portion of all genomic data cannot be explained by our current models and some regions in the genome may have different sequence variation rates [21, 153, 157].

6. All analyzed SNP variants (and some other forms of genetic variation) for many species are collected in the public Single Nucleotide Polymorphism Database (dbSNP) maintained by the National Center for Biotechnology Information (NCBI) in collaboration with the National Human Genome Research Institute (NHGRI). New data are revised and made available in irregular intervals as a series of "builds". Database is available online http://www.ncbi.nlm.nih.gov/SNP [173]. Statistically significant GWAS data concerning SNPs and SNP-trait associations are collected in the online GWAS Catalog provided by the NHGRI and the European Bioinformatics Institute (EMBL-EBI) [205].

7. Copy number variant $(\mathrm{CNV})$ is a segment of DNA $(\geq 1 \mathrm{~kb})$ that can be found in a variable number of copies (in comparison with a reference genome) among individuals [53].

8. Lactase persistence means the ability to maintain the activity of the intestinal lactase gene beyond the infant nursing period and depends on a variant form of the regulatory (enhancer) region that increases the activity of the promoter of the gene [100].

9. Three main populations with traditions in dairy herding differ with occurrence of specific variants of the lactase gene regulatory regions: population of Central and Northern Europe (so-called $\mathrm{T}_{-13910}$ allele, also found among US 
inhabitants of European origin), population of the Middle East $\left(\mathrm{G}_{-13915}-\mathrm{C}_{-3712}\right.$ variant) and Eastern Africa inhabitants $\left(\mathrm{G}_{-13907}\right.$ allele) $[11,46,47,104]$.

10. The fact that approximately $98.5 \%$ of the human genome is not protein-coding forced us to revise our notions about the so-called "non-coding" DNA. These segments are now believed to have regulatory functions and be able to influence complex traits [3, 69, 145, 212].

11. Jia Y. et al. pointed out that the new definition of the gene must accommodate the recent advances in the study of genome (genomics), RNAs (ribonomics) and proteome (proteomics) [91]. Gerstein M.B. et al. defined a gene as "a union of genomic sequences encoding a coherent set of potentially overlapping functional products" [68, p. 677].

12. H. Pearson describes the consortium difficulties: "But reaching a consensus over the definition is virtually impossible, as Karen Eilbeck can attest. Eilbeck, who works at the University of California in Berkeley, is a coordinator of the Sequence Ontology Consortium [...] Eilbeck says that it took 25 scientists the better part of two days to reach a definition of a gene that they could all work with. 'We had several meetings that went on for hours and everyone screamed at each other,' she says. The group finally settled on a loose definition that could accommodate everyone's demands" [143, p. 401].

13. The difference between estimated heritability and the results of the GWAS studies has been especially high for human height, a well-researched polygenic trait. It has been revealed that the GWAS studies which associated more than 40 genetic variants with height differences, have been able to explain about $5 \%$ of phenotypic variance, as compared to expected $80-90 \%$ heritability [76, 110, 119, 121, 202]. Yang J. et al. in their crucial study applied more refined methods of analysis and accounted for 45\% of variance [208]. These data suggest much stronger than expected environmental influence, but other strictly genetic phenomena, such as rare variants or interactions among genetic loci must also be considered [119, 121, 214].

14. The association of FOXP2 with SLI is a result of Foxp2 regulation of the expression of CNTNAP2 gene (contactin associated protein-like 2). Moreover, transcription factor Foxp2 regulates expression of approximately 300 genes in the brain, but for 34 genes this link is exceptionally strong. Such a wide range of FOXP2 gene influence on various processes in the developing brain suggest a possible association with other human abilities and behavioral traits [36, 56, 182, 198]. For example, Foxp2 regulates expression of MET gene (receptor tyrosine kinase), both genes being implicated in higher cognitive dysfunction and ASD (autism spectrum disorder) risk [134]. It has also been proven that expression of FOXP2 gene is regulated by multiple miRNAs, which means possible influence of environmental factors [62].

15. The genes involved are CMIP (c-maf-inducing protein), ATP2C2 (calcium-transporting ATPase, type 2C, member 2), DYX1C1(dyslexia susceptibility 1 candidate 1), KIAA0319, DCDC2 (doublecortin domain containing 2), ROBO1 (roundabout, axon guidance receptor, homolog 1 (Drosophila)), MRPL19 (mitochondrial ribosomal protein L19) and C2ORF3 (GCFC2 GC-rich sequence DNA-binding factor 2) [4, 133, 138, 142, 171].

16. Correlation has been established between cognitive abilities and various genes, such as genes necessary for neurotransmition - DRD2 (dopamine receptor D2),

COMT (catechol-O-methyltransferase), CHRM2 (cholinergic receptor muscarinic 2), MAOA (monoamine oxidase A), $B D N F$ (brain-derived neurotrophic factor) and GRM3 (glutamate receptor, metabotropic 3) or brain function NCSTN (nicastrin), DTNBP1 (dystrobrevin binding protein 1), STX1A (syntaxin 1A), FMR1 (fragile X mental retardation 1) and $U B E 3 A$ (ubiquitin protein ligase E3A). Other studies has shown links with such genes as NPTN (neuroplastin), KCNMA1 (potassium channel, calcium activated large conductance subfamily $\mathrm{M}$ alpha, member 1), NRXN1 (neurexin 1), SCRT (scratch family zinc finger 1) and POU3F2 (POU class 3 homeobox 2). However, some of the previously established correlations has been questioned recently, especially for DRD2, CHRM2, DTNBP1, COMT and BDNF genes [23, 35, 66, 151, 161, 171].

17. The landmark study was published by Caspi A. et al. and proved that the influence of stressful events on depression can be moderated by a polymorphism in the promoter region of the serotonin transporter (5-HTT) gene [22].

18. Turkheimer's comments are a reply to the paper of Plomin R. et al., focusing on the replicability of behavioral genetics data. Turkheimer concludes his analyses that "the activities of people involved in divorce proceedings can be examined at a genetic level of analysis, but (genetic influence notwithstanding) we do not anticipate a time when people will get genetic testing to help them understand difficulties in their marriages [...] Where will such ambiguously psychophysical entities end up on an axis of developmental complexity running from Huntington's disease to divorce? This, not genes versus environment, is the real question posed by behavior genetics. I am more skeptical than most of my colleagues about the reductive power of genetics to explain such things, but I recognize that the scientific jury is still out. In the meantime, all I ask is that inevitable findings of weak genetic influence not be accepted as strong genetic explanations of complex human behavior while we wait for the progress of science to take its inevitable course" [150, 195, p. 26-28].

19. These expectations could put more weight on women and seem to be contradictory, as pointed out by Richardson: "while maternal bodies are conceptualized as having great power to influence future generations and are positioned at the center of the intervention model advanced by $\mathrm{DOHaD}$, the $\mathrm{DOHaD}$ model accords individual women very little power to influence their own outcomes. On the one hand, women are instructed to do all they can to prevent 
harm to their fetus. At the same time, an individual woman can do little to improve outcomes for her own offspring if they are trapped in the intergenerational epigenetic "feedforward cycle" hypothesized by DOHaD research" [159, p. 224]

20. Richardson comments on some more extreme notions: "DOHaD researchers hope that a collateral effect of their policies will be to enhance resources for pregnant women. However, their proposed interventions are directed toward the most efficient methods to ensure developmentally optimum outcomes for the fetus. The symbols favored by $\mathrm{DOHaD}$ researchers - on the insignia of its international society, or the cover of one of the field's leading textbooks, The Fetal Matrix [...] - are fetuses encapsulated in headless, legless maternal abdomens [...] The maternal body is a transducing and amplifying medium necessary to get to the fetus, an obligatory passage point, not a primary endpoint or subject of DOHaD research" [159, p. 223]. See also [70]. 